\title{
Spatial patterns of recruitment in a demersal fish as revealed by seabird diet
}

\author{
Dan P. Robinette*, Julie Howar, William J. Sydeman, Nadav Nur \\ PRBO Conservation Science, Marine Ecology Division, 3820 Cypress Drive \#11, Petaluma, California 94954, USA
}

\begin{abstract}
Understanding recruitment in demersal fish requires determination of larval survival and delivery to appropriate settling habitats. Sanddabs Citharichthys sp. are an abundant neritic fish of Central California, an area of persistent upwelling. 'Upwelling shadows' develop in the lee of coastal promontories, retain surface waters, and may promote spatial variation in fish settlement. To test this hypothesis, we studied the diet and foraging dimensions of a seabird (Cepphus columba) specializing in sanddab consumption at windward and leeward sites over a 6 yr period. We integrated the bird's take of sanddab with information on upwelling intensity and variability and sanddab larval abundance based on net sampling. Seabird diet at both sub-colonies was variable, but dominated by Age 1 sanddabs. Sanddabs were more prevalent in the diet of guillemots at the leeward site, and diet was more variable at the windward site. Persistent upwelling led to regional increases in sanddab larval abundance which, in turn, resulted in enhanced recruitment to leeward waters, as reflected in seabird diet. Pulsed upwelling was related to apparent increased recruitment in windward waters. This study is one of the first to suggest that seabird diet can be used as an indicator of spatial variability in recruitment and settlement of demersal forage fish.
\end{abstract}

KEY WORDS: Pigeon guillemot - Sanddab • Diet - Larval abundance • Coastal promontory • Upwelling shadow $\cdot$ Relaxation $\cdot$ Demersal fish settlement

Resale or republication not permitted without written consent of the publisher

\section{INTRODUCTION}

Recruitment in open marine fish populations is dependent on larval survival and settlement (Caley et al. 1996, Levin 1996). For neritic species, settlement may be affected by spatial variability in oceanographic processes that affect the distribution of larvae as they reach settlement age (Jenkins \& Black 1994, Wing et al. 1998). In eastern boundary current systems, upwelling promotes ocean productivity, but strong, persistent upwelling may advect icthyplankton away from suitable coastal habitats (Cury \& Roy 1989). Recent research has shown that the effect of upwelling on advective processes depends, in part, on coastal topography; in particular, 'upwelling shadows' on the leeward sides of coastal promontories can act as retention areas even when upwelling is strong and persistent (Wing et al. 1995, 1998). Moreover, nutrients entrained within upwelling shadows facilitate primary and sec- ondary productivity for weeks longer than in areas outside shadows (Graham \& Largier 1997).

We tested the hypothesis that recruitment of a demersal fish in an upwelling system varies spatially, with recruitment greater in either windward or leeward habitats depending on the interplay of upwelling effects and coastal topography. While increased upwelling (i.e. more intense and/or more persistent) should increase regional productivity and hence survival of larvae in general, Ekman transport of these larvae could differ on the 2 sides of a coastal promontory (Fig. 1). In windward habitats, increased upwelling may lead to increased offshore advection, reduced recruitment and a reduced Age 1 population the following year. In leeward habitats, increased upwelling may result in an upwelling shadow that will retain larvae and their food. This, in turn, may lead to increased larval recruitment and an increased Age 1 population. Conversely, the Age 1 population should 

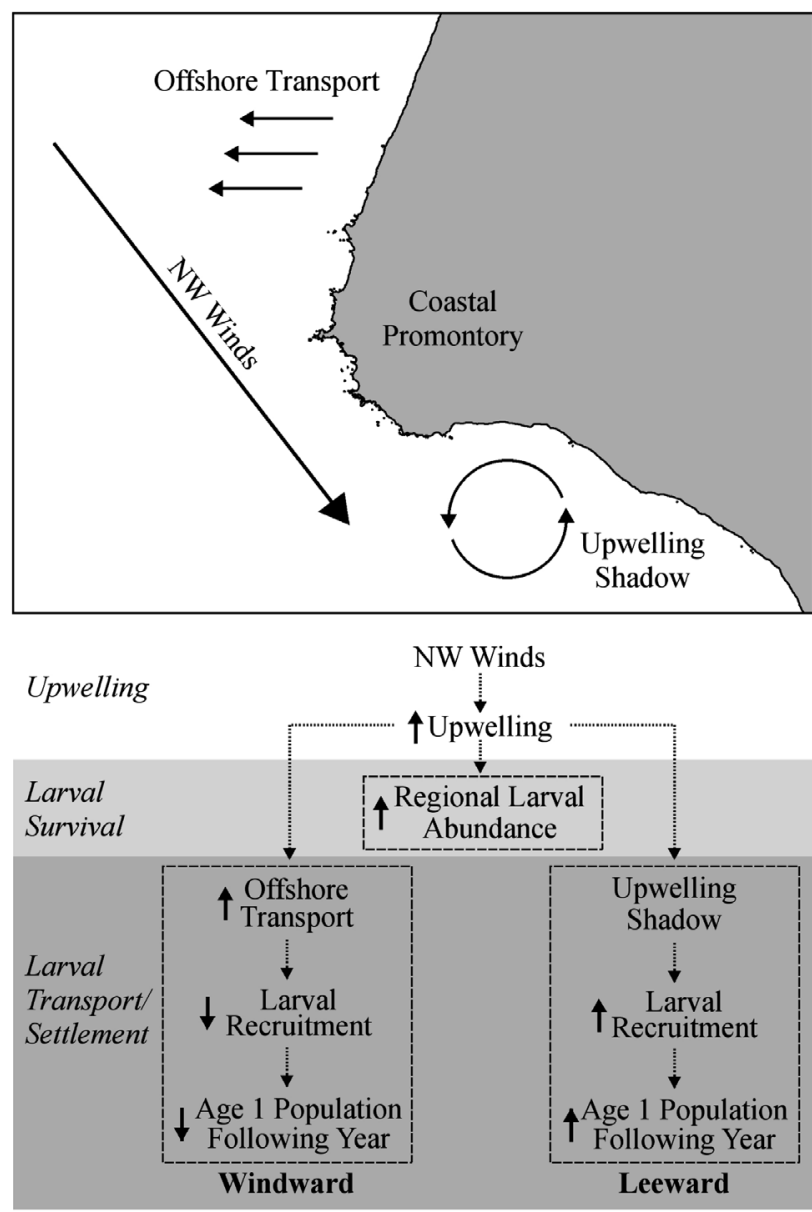

Fig. 1. Theoretical diagram showing the cascading effects of upwelling winds on demersal fish recruitment to windward and leeward habitats around a coastal promontory in Central California

be increased at windward sites and reduced at leeward sites when prior-year upwelling is weak and/or variable. Variable upwelling should result in more relaxation events, and thus, a reduction in net offshore transport at windward sites.

We tested this hypothesis by integrating regional upwelling indices with net samples of sanddab Citharichthys sp. larval abundance and diet of a nearshore seabird, the pigeon guillemot Cepphus columba, collected upstream and downstream from a coastal promontory. Traditional methods for estimating demersal fish recruitment involve trawl samples to estimate agespecific abundance (Caley et al. 1996). We used a similar approach, but substituted trawl samples with seabird diet, which provides a proxy to abundance of Age 1 individuals. This approach is based on research showing that seabirds can be used as reliable indicators of change in prey populations (Sunada et al. 1981, Cairns 1992, Hatch \& Sanger 1992, Montevecchi \& Myers 1995, 1996, Miller \& Sydeman 2004, Abraham \&
Sydeman 2006). However, our approach is novel because we integrate the seabird data with net samples and use seabird diet to test hypotheses of fish settlement to local neritic habitats, a new application.

\section{MATERIALS AND METHODS}

Study area, diet and foraging observations. We studied sanddabs Citharichthys sp., birds Cepphus columba and upwelling at the Point Arguello Promontory, north of Point Conception, Central California (Fig. 2). We defined the promontory as extending from Point Michelle in the north to Sudden Ranch in the south. The coastal habitat here supports $\sim 500$ pairs of breeding pigeon guillemots (D. P. Robinette unpubl. data), with the birds nesting in rock crevices. Though guillemots typically take a diverse array of prey (Follett \& Ainley 1976, Ewins 1993, Litzow et al. 2000), prey specialization has been observed at both the individual and colony level (Golet et al. 2000, Litzow et al. 2000). Specialization is an ideal trait for an indicator species if the predator does not switch to a single alternate prey in the absence of the dominant prey (Anderson \& Gress 1984, Monaghan 1996). This is the case for guillemots at Point Arguello.

We obtained information on diet composition and foraging dimensions of guillemots at 2 sub-colonies,

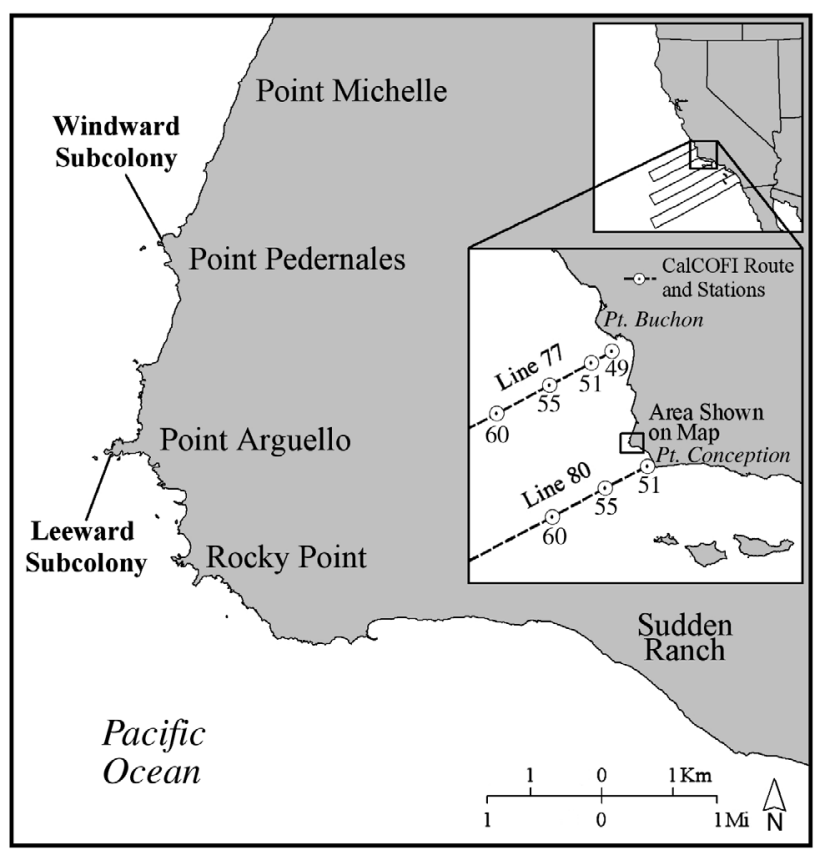

Fig. 2. Map of the Point Arguello Promontory showing the Point Pedernales (windward) and Point Arguello (leeward) sub-colonies. The larger inset map shows nearshore sampling stations along California Cooperative Oceanic Fisheries Investigations (CalCOFI) Lines 77 and 80 . The entire CalCOFI survey route is shown in the smaller inset map 
1 windward and 1 leeward of the Point Arguello Promontory. Point Pedernales, our windward site, is located approximately $3 \mathrm{~km}$ northeast of Point Arguello (Fig. 2). Our leeward site was on the south side of Point Arguello. We made observations during the chickrearing seasons at Point Pedernales from 2000 to 2002 and again from 2004 to 2005 ( $\mathrm{n}=132 \mathrm{~h}$ total) and at Point Arguello from 2001 to 2005 ( $n=206$ h total). During chick-rearing, adults return to breeding crevices with whole prey items in their bills. Adults typically land on the rocks outside crevices, allowing identification of prey type. We located 18 crevices at Point Pedernales and 34 at Point Arguello. Because not all crevices are active during a given year, the annual number of crevices used in our analyses ranged from 7 to 9 at Point Pedernales and from 10 to 25 at Point Arguello. We made observations with binoculars and a spotting scope from approximately $30 \mathrm{~m}$. We identified prey to the lowest taxonomic level possible (usually family) and estimated prey size as a multiple of guillemot bill length. Over all years, we identified a total of 684 prey items at Point Pedernales (windward) and 1201 at Point Arguello (leeward). We used percent sanddab as our basic index of sanddab take by the birds. We calculated percent sanddab as the percent of total identified prey items that were sanddabs. To examine if guillemots take an alternate dominant prey in some years, we also calculated diet diversity using the Shannon-Wiener diversity index given in Brower et al. (1998):

$$
H^{\prime}=-\sum p_{\mathrm{i}} \log _{10} p_{\mathrm{i}}
$$

where $p_{\mathrm{i}}$ is the proportion of total identified prey items from prey group i. This index has a range of values from zero to $\log (S)$, where $S$ is the total number of species in the sample.

Pigeon guillemot foraging directions. Beginning in 2004, we recorded the directions foraging guillemots were leaving in and returning to Point Arguello; in 2005, we extended this effort to Point Pedernales. We made flight observations concurrently with diet observations. At each point, we divided our field of view into north, northwest, west, southwest and south. When birds left the colony, we recorded the direction the bird was last observed flying. For returning birds, we recorded the direction from which they came into view. We recorded a total of 149 departing and 183 returning flights in 2004 and 175 departing and 201 returning flights in 2005 at Point Arguello. We recorded a total of 378 departing and 229 returning flights at Point Pedernales in 2005.

Sanddab larval abundance. We estimated regional sanddab larval abundance using data from the California Cooperative Oceanic Fisheries Investigations (CalCOFI). CalCOFI surveys are conducted on a quarterly basis (winter, spring, summer and fall). We used data from bongo tows conducted at nearshore stations along CalCOFI Lines 77 and 80 (Fig. 2). Ohman \& Smith (1995) have described the methods. Data were standardized by soaking time and provided as number of larvae $\mathrm{m}^{-2}$. Occasionally, 1 or 2 stations were missed during a particular quarterly survey. Additionally, differences among stations can differ by orders of magnitude. We therefore calculated the geometric mean of larval abundance across stations. We calculated geometric means by transect in order to control for transect effects during statistical analyses. Additionally, because sanddab spawning is triggered by temperature changes associated with upwelling and can continue past the upwelling season (Rackowski \& Pikitch 1989), we calculated geometric means of larval abundance for 3 time periods based on CalCOFI surveys: (1) spring and summer, (2) fall and (3) spring, summer and fall.

Upwelling indices. The peak upwelling season along the Central California coast occurs from April through August (Hickey 1979). We estimated the intensity and variability of upwelling using monthly upwelling indices calculated for $36^{\circ} \mathrm{N}, 122^{\circ} \mathrm{W}$ by the Pacific Fisheries Environmental Laboratory (www.pfeg. noaa.gov). We calculated indices using the same time periods used for larval abundance. We used data from April through August for spring to summer larval abundance, September through November for fall, and April through November for spring, summer and fall. We estimated annual upwelling intensity by summing monthly values to create cumulative upwelling indices (CUI) for each time period. We also calculated periodspecific estimates of upwelling variability by calculating the standard deviations of upwelling within a period.

Statistical analyses. We used tests of homogeneity based on the Pearson goodness-of-fit chi-squared statistic to determine if foraging directions varied by subcolony and year. We compared 2004 and 2005 at Point Arguello, as well as Point Arguello and Point Pedernales in 2005. To determine which upwelling variables influenced regional larval abundance and at which temporal scales these processes were working, we created predictive linear models with larval abundance measured at the 3 time periods as dependent variables and upwelling intensity and variability at the 3 time periods as independent variables. We used Mallows' $C_{\mathrm{p}}$ criterion to determine the best model for each dependent variable (Mallow 1973). We put 2 limitations on model selection. First, the maximum number of independent variables used was 3 - the CalCOFI transect plus 2 upwelling variables. Second, we did not use upwelling variables containing fall values to predict the previous spring to summer larval abundance. The dependent variable (larval abundance for the respec- 
tive time period) was log transformed in these analyses to meet assumptions of linear models (Nur et al. 1999). We present standardized regression coefficients (Kutner et al. 2005) to compare among models. Finally, we used the upwelling and larval abundance variables with the strongest association (as indicated by the standardized regression coefficient) in linear models relating these variables to proportion of sanddab in guillemot diet. Based on the mean guillemot bill length reported by Ewins (1993) and the ageclass lengths of sanddabs reported by Rackowski \& Pikitch (1989), we determined that guillemots in our study were taking Age 1 sanddabs. We therefore used a lagged approach in our models, relating upwelling and larval abundance in $\mathrm{yr}^{x}$ to diet in $\mathrm{yr}^{\mathrm{x}+1}$. When modeling the effects of upwelling on guillemot diet, we controlled for larval abundance; when modeling the effects of larval abundance, we controlled for upwelling. Both models used logit-transformed percent sanddab and controlled for CalCOFI transect impacts. We estimated separate slopes for windward and leeward sites for the respective variable of interest (larval abundance or upwelling) in a single model when a statistically significant difference between the slopes was detected. We used STATA 8.2 statistical software (STATA 2005) for all statistical analyses except for tests of homo-geneity, which were done by hand.

\section{RESULTS}

\section{Sanddab consumption by guillemots}

A total of 23 prey species and groups were taken (Tables 1 \& 2). Sanddabs were the dominant prey at both sites in all years. Percent sanddab Citharichthys sp. was strongly negatively correlated with diet diversity at both sites, indicating guillemots Cepphus columba did not switch to a single alternate prey species in years when sanddabs were less available (windward: $\mathrm{r}=-0.900, \mathrm{p}=0.019$; leeward: $\mathrm{r}=-0.900, \mathrm{p}=0.019$ ). Sanddab consumption at the leeward site was more consistent than at the windward site. Annual percent sanddab ranged from $\sim 41$ to $64 \%$ of the diet at the leeward site (Table 2) and from $\sim 24$ to $60 \%$ of the diet at the windward site (Table 1). The coefficient of variation (CV) for the windward site (38.24) was more than twice that of the leeward site (17.36). Overall, mean $( \pm \mathrm{SE})$ annual percent sanddab was greater at the leeward site $(50.28 \pm 3.90, \mathrm{n}=5)$ than at the windward site $(42.94 \pm 7.34)$; the take of sanddab between the sites among years was not significantly correlated $(\mathrm{r}=$ $-0.400, p=0.300)$.

\section{Foraging directions}

There were among-year differences in the directions guillemots left and returned to Point Arguello (leaving: $\chi^{2}=26.93, \mathrm{df}=4, \mathrm{p}<0.005$; returning: $\chi^{2}=26.07, \mathrm{df}=$ $4, \mathrm{p}<0.005)$. However, the majority of guillemots left and returned from the south and southwest in both years (Fig. 3). The most pronounced differences were that guillemots foraged more to the south in 2004 and more to the southwest in 2005. Guillemots from Point Pedernales mainly foraged to the north and northwest (Fig. 4). There were differences in foraging directions between Point Pedernales and Point Arguello (leaving: $\chi^{2}=221.46, \mathrm{df}=4, \mathrm{p}<0.005$; returning: $\chi^{2}=246.40, \mathrm{df}=$ $4, \mathrm{p}<0.005)$. Together, these data suggest that guillemots from Arguello forage leeward, while guillemots from Pederanles forage windward of the promontory. 
Table 2. Cepphus columba. Diet composition ( $\%$ total observations $\mathrm{yr}^{-1}$ ) and diet diversity $\left(H^{\prime}\right.$, Shannon-Wiener index) of pigeon guillemots breeding at the Point Arguello (leeward) sub-colony in 2001 to 2005

\begin{tabular}{|lccccc|}
\hline Prey taxon & 2001 & 2002 & 2003 & 2004 & 2005 \\
\hline Sanddab (Citharichthys sp.) & 64.04 & 53.06 & 46.75 & 41.45 & 46.13 \\
Anchovy (Engraulis mordax) & 0.44 & 0.00 & 0.41 & 15.65 & 5.99 \\
Smelt (Family Osmeridae) & 0.00 & 9.18 & 0.00 & 7.83 & 0.00 \\
Squid (Loligo sp.) & 0.44 & 1.02 & 0.00 & 2.61 & 0.70 \\
Rockfish (Sebastes sp.) & 1.32 & 1.02 & 7.32 & 3.77 & 3.17 \\
Saury (Cololabis saira) & 0.00 & 0.00 & 0.00 & 0.29 & 0.35 \\
Sablefish (Anoplopoma fimbria) & 0.44 & 0.00 & 0.00 & 0.00 & 0.00 \\
Octopus (Octopus sp.) & 8.77 & 15.31 & 16.67 & 0.00 & 0.70 \\
Sculpin (Family Cottidae) & 1.32 & 0.00 & 10.57 & 2.03 & 0.00 \\
Cuskeel (Family Ophidiidae) & 0.00 & 1.02 & 0.00 & 2.61 & 1.41 \\
Kelpfish (Family Clinidae) & 0.00 & 0.00 & 0.41 & 3.19 & 0.70 \\
Greenling (Hexagrammos sp.) & 0.00 & 0.00 & 0.41 & 0.29 & 0.70 \\
Shrimp (Crangon sp.) & 1.75 & 1.02 & 0.81 & 6.09 & 27.82 \\
Blenny (Hypsoblennius sp.) & 0.44 & 0.00 & 0.00 & 0.29 & 1.06 \\
Lingcod (Ophiodon elongatus) & 0.00 & 0.00 & 0.41 & 0.00 & 2.46 \\
Sardine (Sardinops sagax) & 0.44 & 0.00 & 0.00 & 0.87 & 0.35 \\
Midshipman (Porichthys sp.) & 11.40 & 8.16 & 10.16 & 4.06 & 4.93 \\
Surfperch (Family Embiotocidae) & 0.44 & 0.00 & 0.81 & 3.19 & 0.00 \\
Gunnel (Family Pholididae) & 1.75 & 1.02 & 1.63 & 1.45 & 0.00 \\
Prickleback (Family Stichaeidae) & 4.82 & 9.18 & 0.81 & 0.29 & 1.76 \\
Sandcrab (Blepharipoda occidentalis) & 0.00 & 0.00 & 0.00 & 0.00 & 0.70 \\
Poacher (Family Agonidae) & 1.32 & 0.00 & 2.44 & 2.32 & 0.00 \\
Combfish (Zaniolepis sp.) & 0.88 & 0.00 & 0.41 & 1.74 & 1.06 \\
& 228 & 98 & 246 & 345 & 284 \\
& 0.60 & 0.65 & 0.74 & 0.91 & 0.73 \\
\hline
\end{tabular}

\section{Upwelling, regional larval abundance and guillemot diet}

Spring to summer upwelling variability was the best predictor of regional larval abundance for all 3 time periods (Table 3). Fall upwelling variability was also a good predictor of fall larval abundance, and fall upwelling intensity predicted spring to fall larval abundance. Overall, the strongest relationship was between spring to summer upwelling variability and spring to fall larval abundance. Thus, upwelling variability during the spring to summer period appears to be driving regional larval abundance, and the effects of this variability last through fall. The relationship is negative, illustrating that fewer larvae are present when upwelling variability is greatest (Fig. 5).

There was a strong, significant relationship between the proportion of sanddab in the guillemot diet and the spring to summer upwelling variability when controlling for location and larval abundance (Table 4). Furthermore, the effects of upwelling differed between windward and leeward sites, with the tightest relationship and steepest slope occurring with windward diet (Fig. 6).
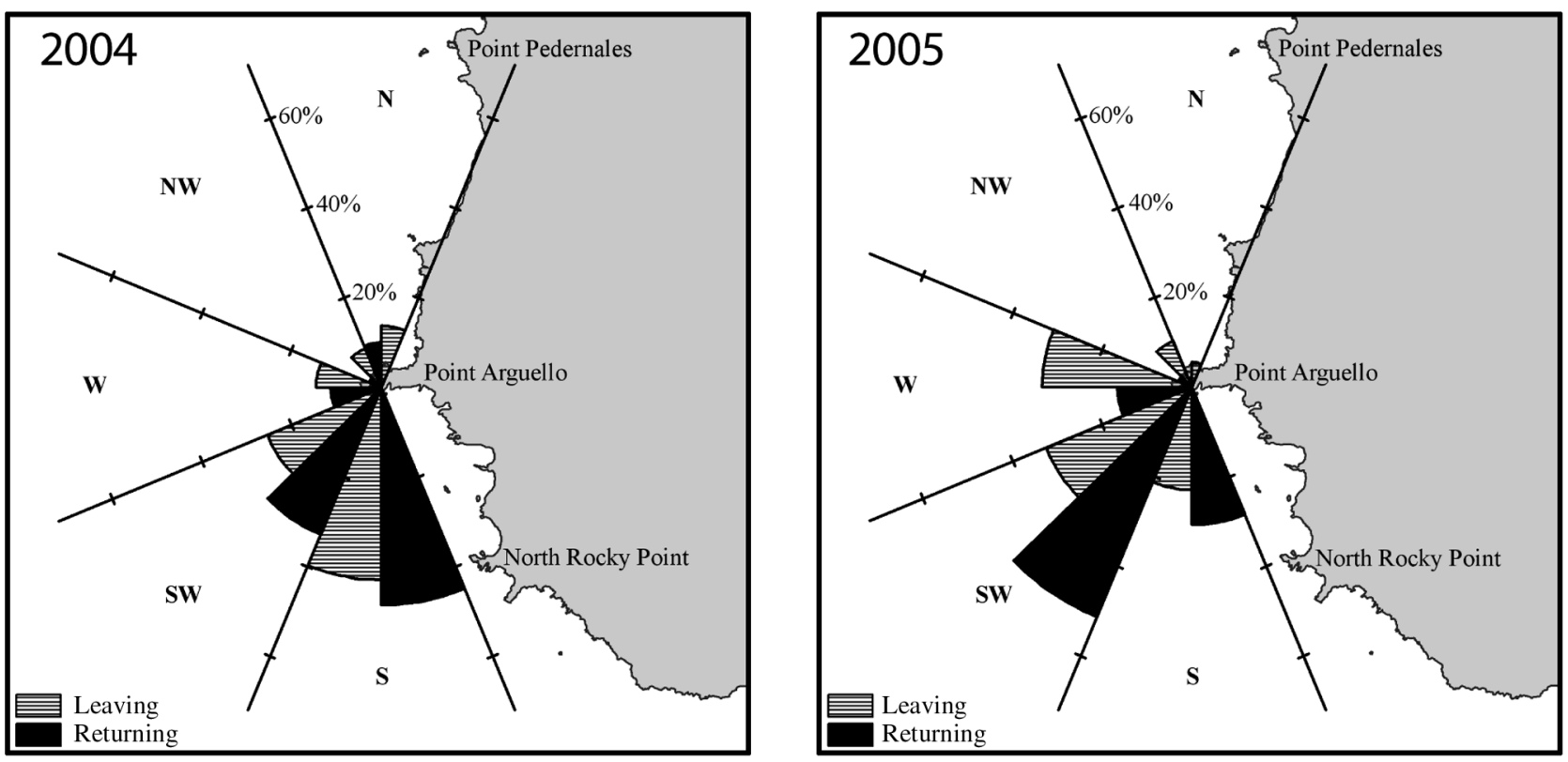

Fig. 3. Cepphus columba. Percent of total guillemots observed leaving and returning in each direction during foraging bouts from Point Arguello (leeward) in 2004 and 2005 


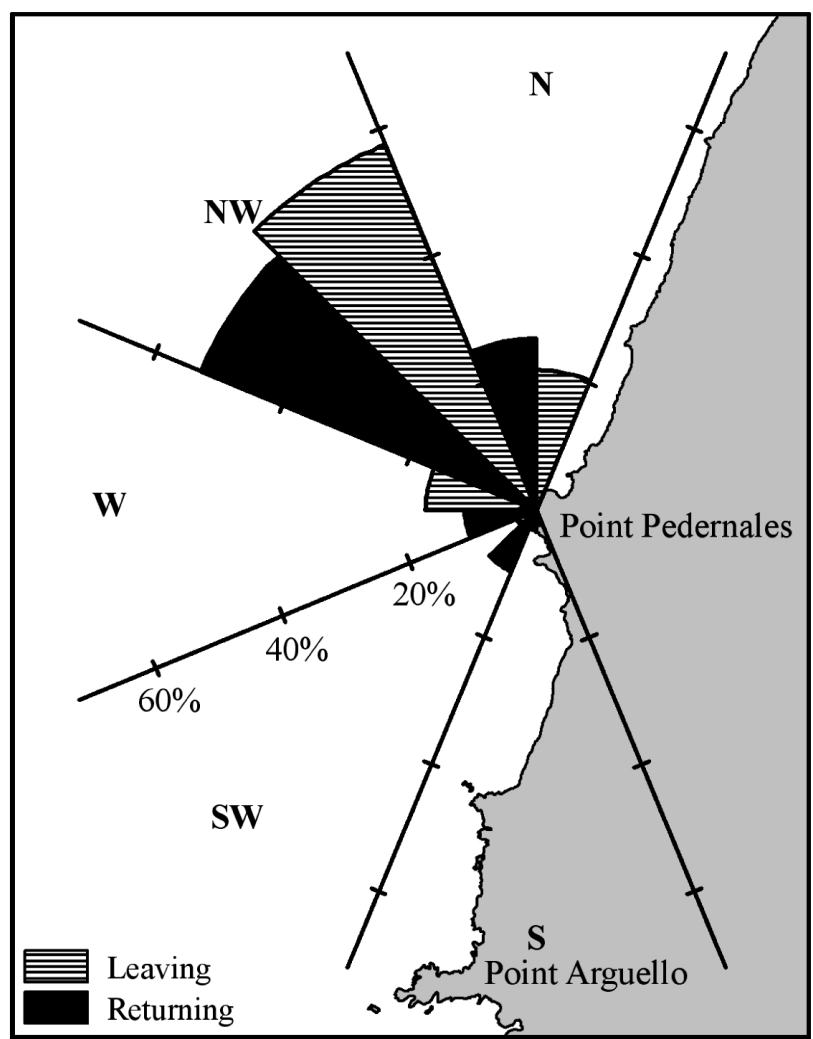

Fig. 4. Cepphus columba. Percent of total guillemots observed leaving and returning in each direction during foraging bouts from Point Pedernales (windward) in 2005

There was also a strong, significant relationship between guillemot diet and spring to fall larval abundance when controlling for location and upwelling variability (Table 5). The effects of larval abundance also differed between sites. Though the slopes for windward and leeward sites were similar, the strongest relationship by far was with leeward diet (Fig. 7). Thus, it appears that windward diet is most affected by variability in Ekman transport during the spring to summer of the previous year, while leeward diet is most affected by larval abundance in the spring to fall of the previous year.

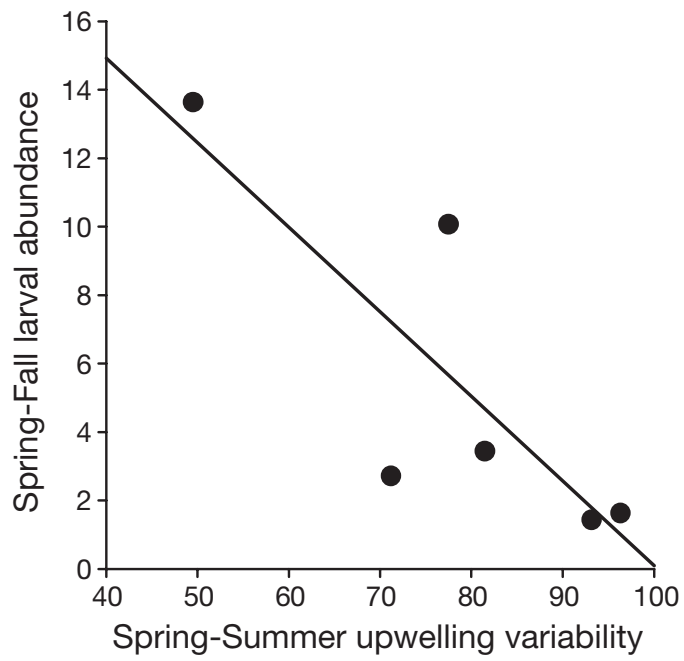

Fig. 5. Citharichthys sp. Scatter plot and regression line of spring to fall larval sanddab abundance versus spring to fall upwelling variability

\section{DISCUSSION}

Our results suggest that persistent upwelling is more important than upwelling intensity in determining regional sanddab Citharichthys sp. larval abundance. If upwelling, regardless of intensity, is short-lived, regional nutrient and phytoplankton concentrations will diminish quickly. Persistent upwelling, however, will have a prolonged impact on regional productivity and thus increase larval survival. Our results support this hypothesis in that more persistent (i.e. less variable) upwelling in our study led to increased regional larval abundance.

The benefits of an upwelling shadow are similar to those of persistent upwelling in that nutrient enrichment and primary productivity are prolonged. In essence, an upwelling shadow is a circulating body of water driven by upwelling-favorable winds (Graham \& Largier 1997). The nutrients retained in this circulation provide for prolonged algal blooms, and thus, prolonged food availability for zooplankton. Though we

Table 3. Citharichthys sp. Optimal predictive models of sanddab larval abundance versus upwelling intensity and variability using Mallows' $C_{\mathrm{p}}$ criterion for each of 3 time periods (spring to summer, fall, and spring to fall). Each model used 0, 1, or 2 upwelling variables and included California Cooperative Oceanic Fisheries Investigations (CalCOFI) transect effects; $k$ : total number of parameters in the model, includes 1 for transect effect. Standardized regression coefficients (beta) are shown. Bold: model with the overall best fit

\begin{tabular}{|llrr|}
\hline Optimal predictive model & Independent variable & Beta & $\mathrm{p}$ \\
\hline Spring-Summer, $k=2, \mathrm{R}^{2}=0.347$ & Spring-Summer upwelling variability & -0.588 & 0.057 \\
Fall, $k=3, \mathrm{R}^{2}=0.798$ & Spring-Summer upwelling variability & 0.800 & 0.001 \\
& Fall upwelling variability & -0.328 & 0.073 \\
Spring-Fall, $\boldsymbol{k}=\mathbf{3}, \mathbf{R}^{2}=\mathbf{0 . 8 4 5}$ & Spring-Summer upwelling variability & $\mathbf{- 0 . 9 4 0}$ & $\mathbf{0 . 4 4 1}$ \\
& Fall upwelling intensity & $\mathbf{0 . 0 0 1}$ \\
\end{tabular}


Table 4. Citharichthys sp. Effects of spring to summer upwelling variability on logit-transformed percent sanddab controlling for spring to fall larval abundance. Site-specific effects (differing between windward and leeward sites) are included. Note slopes for upwelling variability differ significantly between sites $\left(F_{1,5}=48.67, \mathrm{p}<0.001\right)$. Linear model:

$$
F_{4,5}=36.83, \mathrm{p}<0.001, \mathrm{R}^{2}=0.967
$$

\begin{tabular}{|lcccc|}
\hline Factor & Coefficient & $\mathrm{SE}$ & $\mathrm{t}$ & $\mathrm{p}$ \\
\hline Location & -3.072 & 0.434 & -7.08 & 0.001 \\
Larval abundance & 0.144 & 0.017 & 8.28 & $<0.001$ \\
Upwelling variability & & & & \\
Windward site & 0.069 & 0.006 & 11.27 & $<0.001$ \\
Leeward site & 0.031 & 0.006 & 5.13 & 0.004 \\
\hline
\end{tabular}

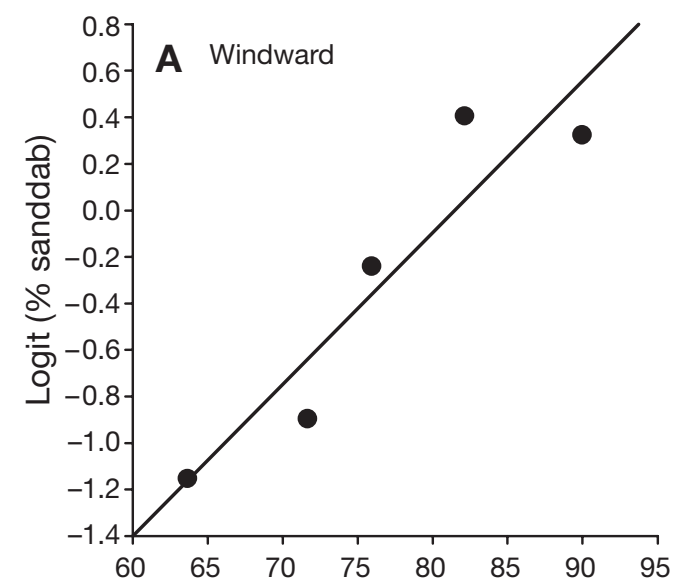

Spring-Summer upwelling variability

Fig. 6. Citharichthys sp. Scatter plots of logit-transformed percent sanddab in the guillemot Cepphus columba diet versus spring to summer upwelling at the: (A) windward and (B) leeward sub-colonies. Values plotted are residuals from the linear model presented in Table 4
Table 5. Citharichthys sp. Effects of spring to fall larval abundance on logit-transformed percent sanddab controlling for spring to summer upwelling variability. Site-specific effects (differing between windward and leeward sites) are included. Note slopes for larval abundance differ significantly between sites $\left(F_{1,5}=12.22, \mathrm{p}=0.017\right)$. Linear model: $F_{4,5}=10.97, \mathrm{p}=$ $0.011, R^{2}=0.898$

\begin{tabular}{|lcccc|}
\hline Factor & Coefficient & $\mathrm{SE}$ & $\mathrm{t}$ & $\mathrm{p}$ \\
\hline Location & 0.496 & 0.233 & 2.13 & 0.087 \\
Upwelling variability & 0.066 & 0.010 & 5.76 & 0.002 \\
Larval abundance & & & & \\
$\quad$ Windward site & 0.112 & 0.032 & 3.47 & 0.018 \\
Leeward site & 0.224 & 0.037 & 6.00 & 0.002 \\
\hline
\end{tabular}

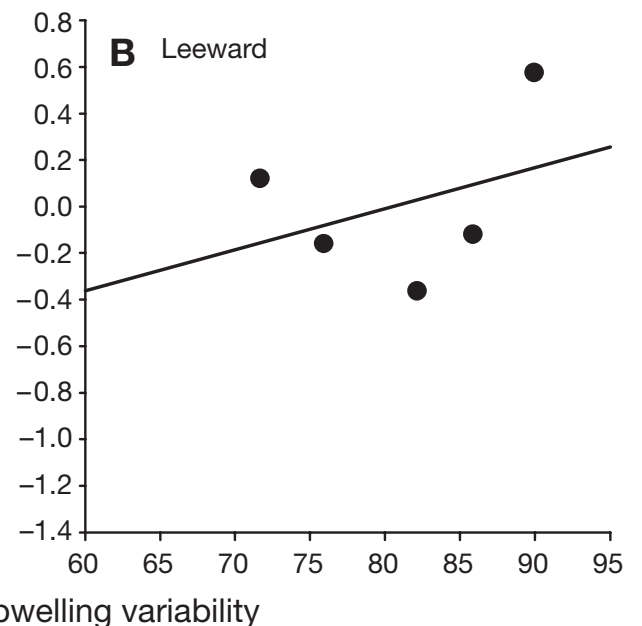

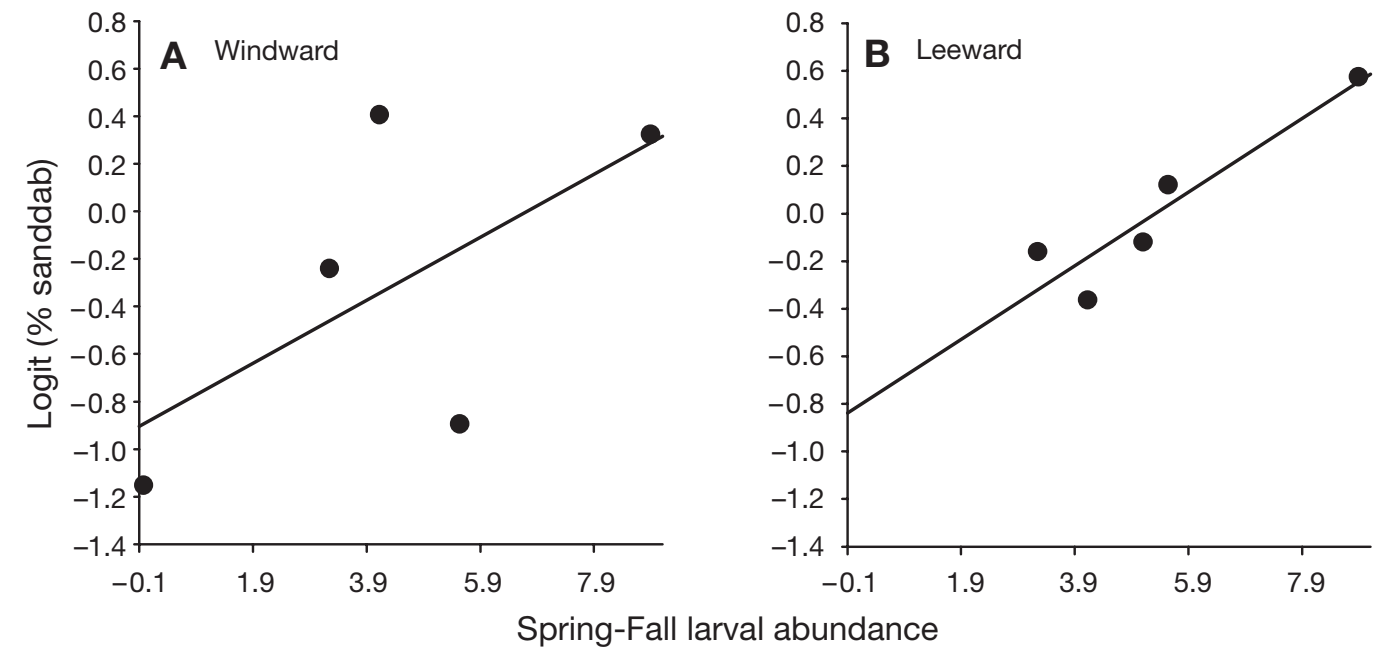

Fig. 7. Citharichthys sp. Scatter plots of logit-transformed percent sanddab in the guillemot Cepphus columba diet versus spring to fall larval abundance at the: (A) windward and (B) leeward sub-colonies. Values plotted are residuals from the linear model presented in Table 5 
expect an upwelling shadow in the lee of Point Arguello, to our knowledge one has never been documented. Trainer et al. (2000) observed a diatom bloom in the lee of Point Arguello that lasted for over $3 \mathrm{wk}$, suggesting the presence of a small, nearshore shadow.

Our results further support the idea of an upwelling shadow in the lee of Point Arguello. Leeward diet had the strongest relationship with prior-year larval abundance, suggesting larvae are not being transported offshore from leeward habitats. Though the relationship between leeward diet and prior-year upwelling variability was significant, it was weak. Thus, variable upwelling may contribute to increased sanddab in the leeward diet during the following year. We expected this relationship to be opposite, since upwelling shadows should be prolonged and more effective during persistent upwelling. However, our results suggest that the upwelling shadow is simply acting as a buffer, minimizing the direct effects of upwelling by maintaining nutrient levels (and thus larval survival) in the leeward area during periods of high variability. This would explain the lower variability in diet at the leeward site. Overall, it appears that the number of larvae fed into the shadow is more important in determining leeward sanddab recruitment than the upwelling event that created the shadow.

Conversely, upwelling variability was very important in determining windward diet, with increased upwelling variability leading to increased sanddab in the windward diet. When upwelling is variable, there are more relaxation events. Relaxation decreases the net offshore transport of larvae by allowing displaced larvae to drift back to nearshore habitats. This has been documented for larvae of other marine species (see Graham \& Largier 1997).

Sanddabs have a long (approximately 270 to 320 d) 5-stage larval cycle, with the earliest stages acting as passive drifters and the later stages capable of remaining nearshore (Sakuma \& Larson 1995). Thus, hydrodynamics during the early larval stages are important in determining the alongshore distribution of settlement-age sanddabs. This is likely why spring to summer upwelling variability had the most impact on windward diet the following year. Sakuma \& Larson (1995) and Sakuma \& Ralston (1995) suggest that early-stage sanddab larvae reside on the offshore side of upwelling fronts. During upwelling events, the larval pool is pushed offshore over the mid-shelf region, where they are subject to further displacement-midshelf transport during the upwelling season is offshore and equatorward (Dever 2004, Ohashi \& Wang 2004, Dong \& Oey 2005).

Conversely, inner shelf transport appears to be very different from mid-shelf transport (Cudaback et al. 2005). In the absence of upwelling-favorable winds, transport over the inner shelf has an onshore tendency. Additionally, the inner shelf experiences much more poleward transport during relaxation than the midshelf, and transport is often poleward, even during upwelling. Thus, larvae that were displaced offshore and equatorward during upwelling can potentially be replaced through poleward transport during periods of relaxation. Cudaback et al. (2005) also noted that transport over the inner shelf responds much more consistently to relaxation than upwelling. We therefore suggest that pulses of relaxation (i.e. variable upwelling) are likely important for recruitment to windward areas and perhaps non-shadow areas in general.

Future research should verify the existence of an upwelling shadow in the lee of the Point Arguello Promontory through the use of advanced very high resolution radiometer (AVHRR) satellite imagery and the fine-scale mapping of surface currents. Additionally, more guillemot Cepphus columba sub-colonies should be studied in order to (1) create replicates of leeward and windward sites and (2) investigate how proximity to the apex of the promontory (i.e. Point Arguello) affects the relationships between sub-colony diet composition and larval abundance and upwelling dynamics. While guillemots at the Point Pedernales sub-colony had a strong tendency toward windward foraging, with very few trips in the leeward direction, foraging directions at the south Point Arguello subcolony were more variable. Though the majority of the trips were in the leeward direction, there was a moderate number toward the west in 2005. Birds departing to the west can potentially forage on either side of the promontory. It is therefore possible that diet at Point Arguello is weakly influenced by windward recruitment. This may have distorted the potential correlation between diet at Arguello and upwelling variability. Preliminary data from a sub-colony on the immediate north side of Point Arguello also showed variable foraging directions, but with a tendency toward windward foraging. We propose adding this sub-colony as our windward replicate, in addition to a sub-colony located at Rocky Point (Fig. 2) as our leeward replicate. This will allow us to investigate whether sub-colonies further away from the apex show stronger correlations in support of our hypotheses. If a given sub-colony is highly dependent on a particular foraging habitat (e.g. windward versus leeward), it will be a better indicator of recruitment to that habitat than if it were influenced by recruitment patterns in both habitats.

In conclusion, this is one of the first studies to use seabird diet as a proxy for recruitment in a demersal fish. We were successful in relating some aspects of diet to the oceanographic factors that likely have a mechanistic influence on sanddab populations on leeward and windward sides of coastal promontories in 
this upwelling system. While our basic premise and methodology (using seabird diet to assess demersal fish availability) is not novel (Mills et al. 2007), relating diet composition to habitat associations and potential mechanistic determinants of recruitment is new. We suggest that the concept of seabirds as indicators of forage fish can be expanded to include spatial as well as temporal components.

Acknowledgements. We thank M. Amaral, A. Brown, N. Collier, K. Gordon and L. Rogan for their help in collecting guillemot diet and foraging data. We thank S. Jacobson and R. Charter for providing data on sanddab larval abundance. We thank N. Francine and Vandenberg Air Force Base for providing us access to study sites. This manuscript was improved by the insights of 3 anonymous reviewers. This research was funded by Department of the Air Force Contracts OSMORD6309386, OSMORD02630104, OSMORD03630085, OSMORD04630108, and OSMORD05630109. This is PRBO Contribution Number 1317.

\section{LITERATURE CITED}

Abraham CL, Sydeman WJ (2006) Prey-switching by Cassin's auklet Ptychoramphus aleuticus reveals seasonal climaterelated cycles of Euphausia pacifica and Thysanoessa spinifera. Mar Ecol Prog Ser 313:271-283

Anderson DW, Gress F (1984) Brown pelicans and the anchovy fishery off southern California. In: Nettleship DN, Sanger GA, Springer PF (eds) Marine birds: their feeding ecology and commercial fisheries relationships. Canadian Wildlife Service Special Publication, Dartmouth, Nova Scotia

Brower JE, Zar JH, von Ende CN (1998) Field and laboratory methods for general ecology. McGraw-Hill, Boston, MA

Cairns DK (1992) Bridging the gap between ornithology and fisheries science: use of seabird data in stock assessment models. Condor 94:811-824

Caley MJ, Carr MH, Hixon MA, Hughes TP, Jones GP, Menge BA (1996) Recruitment and the local dynamics of open marine populations. Annu Rev Ecol Evol Syst $27: 477-500$

Cudaback CN, Washburn L, Dever E (2005) Subtidal innershelf circulation near Point Conception, California. J Geophys Res 110:C10007

Cury P, Roy C (1989) Optimal environmental window and pelagic fish recruitment succession in upwelling areas. Can J Fish Aquat Sci 46(4):670-680

Dever EP (2004) Objective maps of near-surface flow states near Point Conception, California. J Phys Oceanogr 34: 444-461

Dong C, Oey L (2005) Sensitivity of coastal currents near Point Conception to forcing by three different winds: ECMWF, COAMPS, and blended SSM/I-ECMWF-Buoy winds. J Phys Oceanogr 35:1229-1244

Ewins PJ (1993) Pigeon guillemot (Cepphus columba). In: Poole A, Gill F (eds) The birds of North America, No. 49. The Academy of Natural Sciences, Philadelphia, PA, and The American Ornithologists' Union, Washington, DC

Follett WI, Ainley DG (1976) Fishes collected by pigeon guillemots, Cepphus columba (Pallas), nesting on Southeast Farallon Island, California. Calif Fish Game 62:28-31

Golet GH, Kuletz KJ, Roby DD, Irons DB (2000) Adult prey choice affects chick growth and reproductive success in pigeon guillemots. Auk 117(1):82-91

Graham WM, Largier JL (1997) Upwelling shadows as nearshore retention sites: the example of northern Monterey Bay. Cont Shelf Res 17(5):509-532

Hatch SA, Sanger GA (1992) Puffins as samplers of juvenile pollock and other forage fish in the Gulf of Alaska. Mar Ecol Prog Ser 80:1-14

Hickey BM (1979) The California Current System: hypotheses and facts. Prog Oceanogr 12:259-284

Jenkins GP, Black KP (1994) Temporal variability in settlement of a coastal fish (Sillaginodes punctata) determined by low-frequency hydrodynamics. Limnol Oceanogr 39(7): $1744-1754$

Kutner MH, Nachtsheim CJ, Neter J, Li W (2005) Applied linear statistical models. McGraw-Hill Irwin, New York

Levin PS (1996) Recruitment in a temperate demersal fish: Does larval supply matter? Limnol Oceanogr 41(4): 672-679

Litzow MA, Piatt JF, Abookire AA, Prichard AK, Robards MD (2000) Monitoring temporal and spatial variability in sandeel (Ammodytes hexapterus) abundance with pigeon guillemot (Cepphus columba) diets. ICES J Mar Sci 57: 976-986

Mallows CL (1973) Some comments on $C_{\mathrm{p}}$. Technometrics 15: 661-675

Miller AK, Sydeman WJ (2004) Rockfish response to lowfrequency ocean climate change as revealed by the diet of a marine bird over multiple time scales. Mar Ecol Prog Ser 281:207-216

Mills KL, Laidig T, Ralston S, Sydeman WJ (2007) Diets of top predators indicate pelagic juvenile rockfish (Sebastes spp.) abundance in the California Current System. Fish Oceanogr 16(3):273-283

Monaghan P (1996) Relevance of the behavior of seabirds to the conservation of marine environments. Oikos 77 : $227-237$

Montevecchi WA, Myers RA (1995) Prey harvests of seabirds reflect pelagic fish and squid abundance on multiple spatial and temporal scales. Mar Ecol Prog Ser 117:1-9

Montevecchi WA, Myers RA (1996) Dietary changes of seabirds indicate shifts in pelagic food webs. Sarsia 80:313-322

Nur N, Jones SL, Geupel GR (1999) Statistical guide to data analysis of avian monitoring programs. Biological Technical Publication BTP-R6001-1999, USDI Fish and Wildlife Service, Washington, DC

Ohashi K, Wang D (2004) Circulation in the Santa Maria Basin, California, during 1998. J Geophys Res 109:C11012

Ohman MD, Smith PE (1995) A comparison of zooplankton sampling methods in the CalCOFI time series. Calif Coop Ocean Fish Investig Rep 36:153-158

Rackowski JP, Pikitch EK (1989) Species profiles: life histories and environmental requirements of coastal fishes and invertebrates (Pacific Southwest) - Pacific and speckled sanddabs. US Fish and Wildlife Service Biological Report 82(11.107). US Army Corps of Engineers, TR EL-82-4, Waterways Experiment Station, Vicksburg, MS

Sakuma KM, Larson RJ (1995) Distribution of pelagic metamorphic-stage sanddabs Citharichthys sordidus and Citharichthys stigmaeus within areas of upwelling off Central California. Fish Bull 93(3):516-529

Sakuma KM, Ralston S (1995) Distributional patterns of late larval groundfish off Central California in relation to hydrographic features during 1992 and 1993. Calif Coop Ocean Fish Investig Rep 36:179-192

STATA Corp (2005) STATA statistical software: Release 8.2. STATA Corporation, College Station, TX 
Sunada JS, Yamashita IS, Kelly PR, Gress F (1981) The brown pelican as a sampling instrument of age group structure in the northern anchovy population. Calif Coop Ocean Fish Investig Rep 22:65-68

Trainer VL, Adams NG, Bill BD, Stehr CM, Wekell JC (2000) Domoic acid production near California coastal upwelling zones, June 1998. Limnol Oceanogr 45(8):1818-1833

Editorial responsibility: Howard Browman (Associate Editorin-Chief), Storebø, Norway
Wing SR, Largier JL, Botsford LW, Quinn JF (1995) Settlement and transport of benthic invertebrates in an intermittent upwelling region. Limnol Oceanogr 40(2):316-329

Wing SR, Botsford LW, Ralston SV, Largier JL (1998) Meroplanktonic distribution and circulation in a coastal retention zone of the northern California upwelling system. Limnol Oceanogr 43(7):1710-1721

Submitted: September 29, 2006; Accepted: September 3, 2007 Proofs received from author(s): November 2, 2007 